\title{
Congenital Anomalies: Prevalence and Risk Factors
}

\author{
Rizk Francine ${ }^{1}$, Salameh Pascale ${ }^{2}$, Hamadé Aline, \\ ${ }^{1}$ Department of Life and Earth Sciences, Faculty of Sciences, Branch II, Lebanese University, Beirut, Lebanon \\ ${ }^{2}$ Laboratory of Clinical and Epidemiological Research, Faculty of Pharmacy, Lebanese University, Beirut, Lebanon \\ ${ }^{3}$ Department of Biology, Faculty of Sciences II, Lebanese University, Fanar, Lebanon \\ *Corresponding author: aline.hamade@ul.edu.lb
}

Copyright (C) 2014 Horizon Research Publishing All rights reserved.

\begin{abstract}
Objective: The aim of this study is to assess the incidence, types and correlates of congenital anomalies (CA) among stillborn and liveborn infants in two Lebanese hospitals in Mount-Lebanon. Methods: In this cross-sectional study, all the newborns who were born during 9 months period from January to December 2009 $(\mathrm{n}=1000)$ at two hospitals setting in Mount-Lebanon hospital, Lebanon were studied. The newborns were assessed for CA. Neonatal data were extracted from medical records of the nursery. The classification of malformations was based upon the anatomical system affected according to the WHO classification of CA. Results: Of the all 1000 single births, $24(2.4 \%)$ were diagnosed as being congenitally malformed. Cardiovascular system defects and limbs anomalies (4/1000) were mostly detected, followed by genitourinary system $(2 / 1000)$, nervous system $(2 / 1000)$, respiratory system $(2 / 1000)$ malformations and chromosomal anomalies (1/1000). A marked association of parental consanguinity and alcohol consumption of the mother during the pregnancy with increased CA rates was found $(p=0.015$ and $p=0.027$ respectively). Conclusions: The frequency of malformations in the study was approximately similar to previous investigations. The increased incidence of $\mathrm{CA}$ in cases of parental consanguinity prompts the necessity of establishing educational programs to avoid these complications in the offspring.
\end{abstract}

Keywords Newborn, Defects, Epidemiology, Consanguinity, Lebanon

\section{Introduction}

Congenital anomalies (CA) can be defined as structural or functional abnormalities including metabolic disorders, present at birth. These defects of prenatal origin result from defective embryogenesis or intrinsic abnormalities in the development process. Birth defects can be isolated abnormalities or part of a syndrome and continue to be an important cause of neonatal and infant morbidity and mortality $[1,2]$.
Based on the World Health Organization (WHO) report, about 3 million fetuses and infants are born each year with major CA. They are found in approximately $3 \%$ of newborns [3]. Worldwide surveys have shown that birth prevalence of congenital anomalies varies greatly from country to country. It is reported to be as low as $1.07 \%$ in Japan and as high as $4.3 \%$ in Taiwan [4]. In the US, a $2-3 \%$ birth prevalence of congenital anomalies has been reported. The birth prevalence of congenital anomalies in England is 2\% and in South Africa it is $1.49 \%$ [5]. In Lebanon, the incidence of major congenital anomalies has been reported as $1.64 \%$ in Southern Beirut [6]. The variation in rates may be explained by social, racial, ecological, and economical influences [4, 5]. The most common serious congenital disorders are congenital heart defects [7], neural tube defects [8] and Down syndrome [9].

CA can be a cause of infant mortality; among infants with malformation who do not survive, more than $70 \%$ die in the first month of life. Approximately $40 \%$ to $60 \%$ of CA are of unknown origin. The etiology of Congenital Malformation is genetic (30-40\%) and environmental (5 to 10\%). Among the genetic etiology, chromosomal abnormality constitutes $6 \%$, single gene disorders $25 \%$ and multifactorial $20-30 \%$; however, for nearly $50 \%$ of CA, the cause is yet to be known [10]. Consanguineous marriages have been described as an important factor contributing to increased CM. Studies have shown a significantly higher incidence of malformations in offspring of consanguineous parents [11].

The main objective of this study is to establish the prevalence and pattern of CA in neonates in two hospitals in Mount Lebanon between January 2009 and December 2009, and to evaluate their correlates, in order to identify the appropriate strategies for prevention.

Accurate quantification of congenital anomalies within a given population is essential for estimating their burden and documenting the need for prevention, for public health policy development, for planning and implementation of services needed by children with malformations and for evaluating the effects of preventive measures and treatment services. Differences in birth defect rates in different countries and studies could be attributed to true differences among different populations or to different definitions of 
birth defects, different methods, and different time periods for ascertainment.

\section{Methods}

\subsection{Type of the Study}

This is a retrospective hospital based records, cross-sectional study with consecutive sampling of newborns babies, who had been delivered in two Lebanese Hospital, based in Mount-Lebanon, Lebanon. These hospitals serve mainly urban areas in the region and were therefore chosen as an example of an average public health maternity hospital. The survey included 1000 neonates delivered between January 2009 and December 2009. All the charts identified from the Medical Birth Registry of the deliveries taking place at the hospital were reviewed for the presence of $\mathrm{CA}$, based on medical records of antenatal care, delivery care, and pediatric examination of the newborn [12]. All singletons newborns delivered in this hospital during the study period were examined at birth and screened for major CA.

Variables recorded included demographic data: date of birth, sex of the newborn and age of the mother as well as weight, length, head circumference and apgar scores of the newborn [13].

Malformations were classified into systems according to World Health Organization (WHO) recommendations [11]. The abnormalities were divided into several groups relative to the following systems: Genitourinary, Musculoskeletal, Nervous, Gastrointestinal, Cardiovascular and Pulmonary systems and to limbs abnormalities and miscellaneous disorders.

\subsection{Statistical Analysis}

Data were entered and analyzed using SPSS, version 18.0. Descriptive results were presented using mean and standard deviation for continuous variables and percentages for qualitative variables. Bivariate analyses were also conducted: Chi-square test was used to compare between two or more percentages when fulfillment conditions were satisfied. When an expected count was lower than 5 in a cell, Fisher Exact test was used. In addition, Student test was used to compare between two means, after ensuring that variances were homogeneous in both groups of comparison.

Multivariate analyses were carried out: when the dependent variable was dichotomous, a logistic regression was performed using a stepwise descending likelihood ratio method; here we used the Hosmer \& Lemeshow test to ensure sample adequacy. When the dependent variable was quantitative, we used a multiple regression using the stepwise method, after ensuring residual normality, homoscedasticity and absence of colinearity.
Malformation, apgar score, baby's weight and cranial perimeter were considered as dependent variables whereas baby's sex, parental consanguinity, mother's professional status, sibling's malformation, mother's smoking during pregnancy, mother's alcohol consumption during pregnancy, baby conception by in vitro fertilization, prematurity, birth by caesarean section, mother's iron intake during pregnancy, mother's calcium intake during pregnancy, mother's vitamins intake during pregnancy, mother's drug intake during pregnancy, mother's gestity, number of abortions, number of children and mother's age were taken as independent variables. Stillbirth was also taken as a dependent variable, with similar independent variables as above, in addition to the major independent variable of congenital malformation.

\section{Results}

\subsection{Sample Description}

One thousand births were recorded: $862(86.2 \%)$ in the one hospital, and $138(13.8 \%)$ in the other hospital. 512 $(51.2 \%)$ were males and $488(48.8 \%)$ were females. Out of 1000 births, 24 (2.4\%) had a malformation, while 44 (4.4\%) were stillborn or died perinatally. No information was available about 2 birth $(0.2 \%)$.

The mean maternal age was observed to be $25.97 \pm 9.7 .632$ (63.2\%) and 368 (36.8\%) newborns were delivered by natural vaginal delivery (NVD) and cesarean section (CS) respectively.

The prevalence of CA among 1000 hospital live births was $2.4 \%$ (24/1000 total births). The frequency distribution of the 24 cases of newborns with birth defects according to the diagnosis of the affected system or abnormality is shown in Table 1. The commonest detected anomalies were those of the congenital cardiovascular disease (16.6\%) and limb anomalies (16.6\%); polydactyly (12.5\%) and abnormal palmar creases $(4,16 \%)$. Musculoskeletal system, genitourinary system, central nervous system and respiratory system involved $8.4 \%$ of the cases for each system. Chromosomal anomalies represented by Down's syndrome, were found in 1 of the $24 \mathrm{CA}$ cases $(4.16 \%)$.

\subsection{Comparison between Births with and without Congenital Malformation}

Parents' consanguinity $(\mathrm{p}=0.015)$, mother's alcohol consumption during pregnancy $(\mathrm{p}=0.027)$, stillbirth or perinatal death $(\mathrm{p}<0.001)$, and mother's drugs intake during pregnancy $(p<0.001)$ were all positively associated with congenital malformation; meanwhile, mother's calcium intake during pregnancy $(\mathrm{p}=0.013)$ was inversely associated with congenital malformation (Table 2). 
Table 1. Systemic distribution and percentage of congenital malformations (CA) among 1000 birth

\begin{tabular}{|ccc|}
\hline Malformation/System & $\begin{array}{c}\text { Number of births with the corresponding } \\
\text { malformation } \\
(/ 24 \text { cases })\end{array}$ & $\begin{array}{c}\text { Percentage of distribution of the } \\
\text { corresponding malformation } \\
(/ 24 \text { cases })\end{array}$ \\
\hline Cardiovascular system & 4 & 16.66 \\
\hline Nervous system & 2 & 8.4 \\
\hline Respiratory system & 2 & 8.4 \\
\hline Genitourinary system & 2 & 8.4 \\
\hline Musculoskeletal system & 2 & 8.4 \\
\hline Anomalies of limbs & 4 & 16.66 \\
\hline Eye, ear, face, Neck & 1 & 4.1 \\
\hline Behcet syndrome & 1 & 4.1 \\
\hline Cephalohematoma & 1 & 4.1 \\
\hline Chromosomal Abnormalities & 1 & 4.1 \\
\hline Miscellaneous & 4 & 16.66 \\
\hline Total & 24 & $(100 \%)$ \\
\hline
\end{tabular}

Table 2a. Characteristics related to births with or without congenital malformations

\begin{tabular}{|c|c|c|c|c|c|}
\hline \multicolumn{2}{|c|}{ Characteristics } & \multirow{2}{*}{$\begin{array}{c}\begin{array}{c}\text { No congenital } \\
\text { malformation } \\
\mathrm{N}=974(97.6 \%)\end{array} \\
842(97.8 \%) \\
132(96.4 \%) \\
\end{array}$} & \multirow{2}{*}{$\begin{array}{c}\text { Congenital } \\
\text { malformation } \\
\mathrm{N}=24(2.4 \%)\end{array}$} & \multirow{2}{*}{$\begin{array}{c}\mathrm{p} \text {-value } \\
0.360^{*}\end{array}$} & \multirow{2}{*}{$\begin{array}{r}\text { Total } \\
\mathrm{N}=998 \\
861 \\
137\end{array}$} \\
\hline Hospital & $\begin{array}{l}1 \\
2\end{array}$ & & & & \\
\hline Sex & $\begin{array}{c}\text { Females } \\
\text { Males }\end{array}$ & $\begin{array}{l}476(97.9 \%) \\
498(97.3 \%) \\
\end{array}$ & $\begin{array}{l}10(2.1 \%) \\
14(2.7 \%) \\
\end{array}$ & 0.485 & $\begin{array}{l}486 \\
512 \\
\end{array}$ \\
\hline $\begin{array}{l}\text { Consanguinity of } \\
\text { Parents }\end{array}$ & $\begin{array}{c}\text { No } \\
\text { First degree } \\
\text { Second degree } \\
\text { or more }\end{array}$ & $\begin{array}{c}790(98.3 \%) \\
123(94.6 \%) \\
61(95.3 \%) \\
\end{array}$ & $\begin{array}{c}14(1.7 \%) \\
7(5.4 \%) \\
3(4.7 \%)\end{array}$ & $0.015^{*}$ & $\begin{array}{c}804 \\
130 \\
64\end{array}$ \\
\hline Mother works & $\begin{array}{l}\text { No } \\
\text { yes }\end{array}$ & $\begin{array}{c}936(97.6 \%) \\
38(97.4 \%) \\
\end{array}$ & $\begin{array}{c}23(2.4 \%) \\
1(2.6 \%) \\
\end{array}$ & $0.620^{*}$ & $\begin{array}{c}959 \\
39 \\
\end{array}$ \\
\hline Siblings malformation & $\begin{array}{l}\text { No } \\
\text { Yes }\end{array}$ & $\begin{array}{c}941(97.5 \%) \\
33(100 \%)\end{array}$ & $\begin{array}{c}24(2.5 \%) \\
0 \\
\end{array}$ & 1.000 & $\begin{array}{c}965 \\
33\end{array}$ \\
\hline $\begin{array}{l}\text { Smoking mother } \\
\text { during pregnancy }\end{array}$ & $\begin{array}{l}\text { No } \\
\text { Yes }\end{array}$ & $\begin{array}{l}790(97.8 \%) \\
184(96.8 \%)\end{array}$ & $\begin{array}{c}18(2.2 \%) \\
6(3.2 \%)\end{array}$ & 0.433 & $\begin{array}{l}808 \\
190 \\
\end{array}$ \\
\hline $\begin{array}{l}\text { Mother consumed } \\
\text { alcohol during } \\
\text { Pregnancy }\end{array}$ & $\begin{array}{l}\text { No } \\
\text { Yes }\end{array}$ & $\begin{array}{l}964(97.8 \%) \\
9(81.8 \%)\end{array}$ & $\begin{array}{l}22(2.2 \%) \\
2(18.2 \%)\end{array}$ & 0.027 & $\begin{array}{c}986 \\
11\end{array}$ \\
\hline $\begin{array}{l}\text { Baby conception by } I n \\
\text { vitro fertilization }\end{array}$ & $\begin{array}{l}\text { No } \\
\text { Yes }\end{array}$ & $\begin{array}{c}969(97.6 \%) \\
5(100 \%)\end{array}$ & $\begin{array}{c}24(2.4 \%) \\
0 \\
\end{array}$ & 1.000 & $\begin{array}{c}993 \\
5\end{array}$ \\
\hline Premature birth & $\begin{array}{l}\text { No } \\
\text { Yes }\end{array}$ & $\begin{array}{l}693(98.0 \%) \\
280(96.6 \%) \\
\end{array}$ & $\begin{array}{l}14(2.0 \%) \\
10(3.4 \%) \\
\end{array}$ & 0.170 & $\begin{array}{l}707 \\
290 \\
\end{array}$ \\
\hline $\begin{array}{l}\text { Birth by Caesarean } \\
\text { section }\end{array}$ & $\begin{array}{l}\text { No } \\
\text { Yes }\end{array}$ & $\begin{array}{l}618(97.9 \%) \\
356(97.0 \%)\end{array}$ & $\begin{array}{l}13(2.1 \%) \\
11(3.0 \%)\end{array}$ & 0.351 & $\begin{array}{l}631 \\
367\end{array}$ \\
\hline $\begin{array}{l}\text { Stillbirth or perinatal } \\
\text { death }\end{array}$ & $\begin{array}{l}\text { No } \\
\text { Yes }\end{array}$ & $\begin{array}{l}937(98.1 \%) \\
37(86.0 \%)\end{array}$ & $\begin{array}{l}18(1.9 \%) \\
6(14.0 \%)\end{array}$ & $<0.001$ & $\begin{array}{c}955 \\
43\end{array}$ \\
\hline $\begin{array}{c}\text { Mother took iron during } \\
\text { pregnancy }\end{array}$ & $\begin{array}{l}\text { No } \\
\text { Yes }\end{array}$ & $\begin{array}{l}146(95.4 \%) \\
827(98.0 \%) \\
\end{array}$ & $\begin{array}{c}7(4.6 \%) \\
17(2.0 \%) \\
\end{array}$ & 0.079 & $\begin{array}{l}153 \\
844 \\
\end{array}$ \\
\hline $\begin{array}{c}\text { Mother took calcium } \\
\text { during pregnancy }\end{array}$ & $\begin{array}{l}\text { No } \\
\text { Yes } \\
\end{array}$ & $\begin{array}{l}202(95.3 \%) \\
772(98.2 \%) \\
\end{array}$ & $\begin{array}{l}10(4.7 \%) \\
14(1.8 \%) \\
\end{array}$ & 0.013 & $\begin{array}{l}212 \\
786 \\
\end{array}$ \\
\hline $\begin{array}{l}\text { Mother took vitamins } \\
\text { during pregnancy }\end{array}$ & $\begin{array}{l}\text { No } \\
\text { Yes }\end{array}$ & $\begin{array}{l}831(97.3 \%) \\
143(99.3 \%) \\
\end{array}$ & $\begin{array}{c}23(2.7 \%) \\
1(0.7 \%) \\
\end{array}$ & 0.236 & $\begin{array}{l}854 \\
144 \\
\end{array}$ \\
\hline $\begin{array}{c}\text { Mother took other drugs } \\
\text { during } \\
\text { Pregnancy }\end{array}$ & $\begin{array}{l}\text { No } \\
\text { Yes }\end{array}$ & $\begin{array}{l}839(98.4 \%) \\
135(93.1 \%)\end{array}$ & $\begin{array}{l}14(1.6 \%) \\
10(6.9 \%)\end{array}$ & $<0.001$ & $\begin{array}{l}853 \\
145\end{array}$ \\
\hline
\end{tabular}


Table 2b. Characteristics of births with and without congenital malformation (continued)

\begin{tabular}{|c|c|c|c|}
\hline Characteristics & $\begin{array}{c}\text { No congenital l malformation } \\
\text { N=974 } \\
\text { Mean (SD) }\end{array}$ & $\begin{array}{c}\text { Congenital malformation } \\
\text { N=24 } \\
\text { Mean (SD) }\end{array}$ & p-value \\
\hline Mother's age & $28.54(6.02)$ & $2.96(2.03)$ & 0.874 \\
\hline Mother's gestity & $2.65(1.74)$ & $0.92(1.14)$ & 0.387 \\
\hline Mother's number of abortions & $0.69(1.10)$ & $1.58(1.53)$ & 0.323 \\
\hline Mother's number of live children & $1.64(1.36)$ & $2908.95(584.02)$ & 0.847 \\
\hline Weight of the baby (in kg) & $3154.98(477.11)$ & $48.56(3.03)$ & 0.027 \\
\hline Height of the baby (in cm) & $49.62(2.35)$ & $33.44(1.72)$ & 0.058 \\
\hline Cranial perimeter of the baby (in cm) & $33.97(1.77)$ & $5.71(3.63)$ & 0.209 \\
\hline Apgar score at 5 min & $8.80(1.82)$ & $<0.001$ \\
\hline
\end{tabular}

Table 3. Multivariate analyses of congenital malformations and other birth characteristics

\begin{tabular}{|c|c|c|c|c|c|c|}
\hline $\begin{array}{c}\text { Dependent } \\
\text { variables }\end{array}$ & Independent variables & $\begin{array}{l}\text { ORa } \\
/ \text { Beta }\end{array}$ & {$[95 \% \mathrm{CI}]$} & p-value & $\mathrm{R}^{2}$ & H-L* \\
\hline $\begin{array}{l}\text { Congenital } \\
\text { malformation }\end{array}$ & $\begin{array}{l}\text { Parents consanguinity } \\
\text { Mother's consumption of } \\
\text { alcohol } \\
\text { Mother's consumption of } \\
\text { drugs }\end{array}$ & $\begin{array}{c}1.72 \\
10.42 \\
5.23\end{array}$ & $\begin{array}{c}0.94 ; 3.15 \\
1.91 ; 56.73 \\
2.20 ; 12.42\end{array}$ & $\begin{array}{c}0.078 \\
0.007 \\
<0.001\end{array}$ & 0.10 & 0.629 \\
\hline $\begin{array}{l}\text { Perinatal birth } \\
\text { /stillbirth }\end{array}$ & $\begin{array}{c}\text { Congenital malformations } \\
\text { Caesarean section delivery } \\
\text { Lower gestity } \\
\text { Mother's number of abortions }\end{array}$ & $\begin{array}{l}7.63 \\
1.86 \\
1.72 \\
1.73 \\
\end{array}$ & $\begin{array}{c}2.67 ; 21.79 \\
0.98 ; 3.55 \\
1.23 ; 2.38 \\
1.13 ; 2.66 \\
\end{array}$ & $\begin{array}{c}<0.001 \\
0.058 \\
0.001 \\
0.013 \\
\end{array}$ & 0.16 & 0.551 \\
\hline Apgar score & $\begin{array}{l}\text { Mother's number of live } \\
\text { children } \\
\text { Mother's smoking during } \\
\text { pregnancy } \\
\text { Mother's vitamins intake } \\
\text { Mother's iron intake } \\
\text { In vitro Fertilization } \\
\text { conception } \\
\text { Parents' consanguinity }\end{array}$ & $\begin{array}{c}0.16 \\
-0.45 \\
0.54 \\
0.40 \\
-1.79 \\
-0.22\end{array}$ & $\begin{array}{c}0.07 ; 0.25 \\
-0.76 ;-0.15 \\
0.20 ; 0.89 \\
0.06 ; 0.73 \\
-3.49 ;-0.10 \\
-0.44 ;-0.01\end{array}$ & $\begin{array}{c}<0.001 \\
0.004 \\
0.002 \\
0.020 \\
0.038 \\
0.048\end{array}$ & 0.04 & NA \\
\hline Baby's weight & $\begin{array}{c}\text { Mother's smoking } \\
\text { Caesarean section delivery }\end{array}$ & $\begin{array}{l}-236.74 \\
-74.03 \\
\end{array}$ & $\begin{array}{c}-313.91 ;-159.57 \\
-136.72 ;-11.35 \\
\end{array}$ & $\begin{array}{l}<0.001 \\
<0.001 \\
\end{array}$ & 0.04 & NA \\
\hline $\begin{array}{l}\text { Baby's cranial } \\
\text { perimeter }\end{array}$ & $\begin{array}{c}\text { Siblings congenital } \\
\text { malformation } \\
\text { Mother's number of abortions } \\
\text { Mother's smoking } \\
\text { Prematurity } \\
\end{array}$ & $\begin{array}{r}1.52 \\
0.19 \\
-0.34 \\
-0.26\end{array}$ & $\begin{array}{l}0.84 ; 2.19 \\
0.07 ; 0.30 \\
-0.63 ;-0.06 \\
-0.51 ;-0.01\end{array}$ & $\begin{array}{c}<0.001 \\
0.001 \\
0.019 \\
0.042\end{array}$ & 0.05 & NA \\
\hline
\end{tabular}

*H-L: Hosmer \& Lemeshow test for sample adequacy

However, hospital, sex, mother's working status, siblings congenital malformation, mother's smoking during pregnancy, baby's conception by in vitro fertilization, premature birth, birth by caesarean section, and mother's iron and vitamins intakes during pregnancy were not significantly associated with congenital malformation $(\mathrm{p}>0.05)$ (Table 2)

Moreover, congenital malformation was significantly associated with relatively low weight of the baby $(\mathrm{p}=0.027)$ and relatively low apgar scores at 5 minutes $(\mathrm{p}<0.001)$. However, mean mother's age, gestity, number of abortions and of live children, and baby's cranial perimeter did not significantly when comparing between babies with or without congenital malformation. Additionally, concerning baby's height, there was a trend towards lower height in babies with congenital malformation $(\mathrm{p}=0.058)$ (Table 2$)$.

\subsection{Multivariate Analyses}

Parents consanguinity ( $\mathrm{ORa}=1.72)$, mother's consumption of alcohol and drugs $(\mathrm{ORa}=10.42, \mathrm{ORa}=5.23$ respectively) were associated with higher risk of congenital malformation. Factors correlated with perinatal death/stillbirth included CA $(\mathrm{ORa}=7.63)$, delivery by caesarian section $(\mathrm{ORa}=1.86)$, mother's lower gestity $(\mathrm{ORa}=1.72)$ and increased number of abortions $(\mathrm{ORa}=1.73)$ (Table 3$)$.

Apgar score correlates positively to mother's number of live children, vitamins and iron intakes during pregnancy; 
whereas, it was significantly decreased by mother's smoking during pregnancy, in vitro fertilization and parents' consanguinity. Baby's weight was negatively affected by mother's smoking during pregnancy and inversely correlated to the caesarean section delivery. Baby's cranial perimeter was increased by siblings' CA, mother's number of abortions; and was decreased by mother's smoking during pregnancy and prematurity. However, for all models, the dependent variables variance percentages explained by the model were relatively low.

\section{Discussion}

Our population-based study involved 1000 newborns in 2 hospitals in Mount-Lebanon between January and December 2009. Our data was based on the hospital's medical records. Out of 1000 infants, 24 were born with CA, thereby the incidence rate of $\mathrm{CA}$ is $2.4 \%$. Most of the malformed stillbirths in the present study were cases with cardiovascular congenital anomalies (16.6\%) and limb anomalies (16.6\%) including polydactyly (12.2\%) and abnormal palmar crease $(4.16 \%)$. Previous reports on the incidence of congenital anomalies in different populations show similar rates reported by Libyan Arab Jamahiriya [14] and Oman [15], Spain [16], Iran [17] and India [18]. The frequency of CA in our study was lower than that reported by Saudi Arabia [19] and Egypt [4]. However, it was higher than the frequencies reported in Kuwait [16], UAE [15] and the region of West Beirut [6]. All incidences reside within the same range and without differences.

Consanguinity is important factor which was found to increase the risk of CA [20-22]. In Lebanon, as in Middle Eastern communities, consanguinity is high [23]. This study reports a significant positive association between the consanguinity and CA in the Lebanese population.

Many studies have demonstrated male predominance amongst congenital malformed babies. In our study, the gender of the fetus had no effect on the incidence of CA, which concurs with the findings of Lei [24] and both genders are equally distributed $[5,24]$.

Maternal age is an important parameter in the birth of a congenitally malformed fetus [25]. In Turkey, studies show that $5.2 \%$ of the mothers are older mothers (35 years of age or older) [26] and $8.7 \%$ of anomalous births were from older mothers, although this was not statistically significant [25]. However in our study this correlation was not evident. It may be due to the relatively small number of cases included in the study with the percentage of women being above 35 years $14.1 \%$ (141/999) giving birth to $8.33 \%(2 / 24)$ of malformed fetuses vs $84.4 \%(844 / 999)$ of the women being between $18-35$ y and giving birth to $87.5 \%(21 / 24)$ of malformed fetuses.

Because of the high frequency of cardiovascular defects as revealed by our investigations, we recommend their proper prenatal diagnosis both by abdominal sonography and echocardiography. We thus recommend that all neonates should be thoroughly examined and investigated for CA. In addition, a Lebanese registry of CA is needed; appropriate health education about consanguinity and genetic counseling for consanguineous couples should also be established before marriage.

In addition to this, there is a need for more extensive, nationwide screening studies to determine the birth prevalence, types and distribution of congenital anomalies in the Lebanese population and the establishment of an ongoing surveillance system for congenital anomalies.

\section{Acknowledgments}

We would like to thank the hospitals that participated in the study. We would also like to thank Stéphanie Atallah and Roland Abi Nahed for their collaboration, effort and contribution to this study.

\section{REFERENCES}

[1] Rosano A et al. Infant mortality and congenital anomalies from 1950 to 1994: an international perspective. Journal of epidemiology and community health 2000;54:660-6.

[2] Agha MM et al. Determinants of survival in children with congenital abnormalities: a long-term population-based cohort study. Birth defects research Part A, Clinical and molecular teratology 2006;76:46-54.

[3] Kalter $\mathrm{H}$ et al. Congenital malformations: etiologic factors and their role in prevention (first of two parts). The New England journal of medicine 1983;308:424-31.

[4] Temtamy S et al. A genetic epidemiological study of malformations at birth in Egypt. Eastern Mediterranean Health journal 1998;4:252-9.

[5] Biri A et al. Birth prevalence and distribution of congenital anomalies in a university hospital. PerinatolDergisi 2005; 13:86-90.

[6] Bittar Z. Major congenital malformations presenting in the first 24 hours of life in 3865 consecutive births in south of Beirut. Incidence and pattern. Le Journal medical libanais The Lebanese medical journal 1998;46:256-60.

[7] Lin AE et al. Cardiovascular malformations: changes in prevalence and birth status, 1972-1990. American journal of medical genetics 1999;84:102-10.

[8] Centers for Disease C, Prevention. Improved national prevalence estimates for 18 selected major birth defects--United States, 1999-2001. MMWR Morbidity and mortality weekly report 2006;54:1301-5.

[9] Wen SW et al. Patterns of infant mortality caused by major congenital anomalies. Teratology 2000;61:342-6.

[10] Rajangam S et al. Consanguinity and chromosomal abnormality in mental retardation and or multiple congenital anomaly. Journal of the Anatomical Society of India 2007;56:30-3. 
[11] Kupka K. International classification of diseases: ninth revision. WHO chronicle 1978;32:219-25.

[12] Cnattingius $\mathrm{S}$ et al. A quality study of a medical birth registry. Scandinavian journal of social medicine 1990;18:143-8.

[13] Juretschke LJ. Apgar scoring: its use and meaning for today's newborn. Neonatal network: NN 2000;19:17-9.

[14] Mir NA et al. Easily identifiable congenital malformations in children: Survey of incidence and pattern in 32,332 live born neonates. Annals of Saudi medicine 1992;12:366-71.

[15] Sawardekar KP. Profile of major congenital malformations at Nizwa Hospital, Oman: 10-year review. Journal of paediatrics and child health 2005;41:323-30.

[16] Madi SA et al. Profile of major congenital malformations in neonates in Al-Jahra region of Kuwait. Eastern Mediterranean health journal $=\mathrm{La}$ revue de sante de la Mediterranee orientale $=$ al-Majallah al-sihhiyah li-sharq al-mutawassit 2005;11:700-6.

[17] Ahmadzadeh A et al. Congenital malformations among live births at Arvand hospital, Ahwaz Iran - A prospective study. Pakistan Journal of Medical Sciences 2008;24:33-7.

[18] Verma $\mathrm{M}$ et al. Congenital malformations--a retrospective study of 10,000 cases. Indian journal of pediatrics 1991;58:245-52.

[19] Fida NM et al. A prospective study of congenital malformations among live born neonates at a University
Hospital in Western Saudi Arabia. Saudi medical journal 2007;28:1367-73.

[20] Al-Jarallah AS. Down's syndrome and the pattern of congenital heart disease in a community with high parental consanguinity. Medical science monitor : international medical journal of experimental and clinical research 2009;15:CR409-12.

[21] el-Shafei A et al. Congenital malformations and consanguinity. The Australian \& New Zealand journal of obstetrics \& gynaecology 1986;26:168-72.

[22] Tayebi $\mathrm{N}$ et al. The prevalence of congenital malformations and its correlation with consanguineous marriages. Oman medical journal 2010;25:37-40.

[23] Barbour B et al. Consanguinity in Lebanon: prevalence, distribution and determinants. Journal of biosocial science 2009;41:505-17.

[24] Lei Z. [Epidemiology of birth defects among children in 8 provinces in China]. Zhonghua yi xue za zhi 1992;72:412-5, 46-7.

[25] Hollier LM et al. Cunningham FG. Maternal age and malformations in singleton births. Obstetrics and gynecology 2000;96:701-6.

[26] Studies HUIoP. Turkey Demographic and Health Survey 2003. In: Hacettepe University Institute of Population Studies MoHGDoMaCHaFP, State Planning Organization and European Union, editor. Ankara, Turkey2004. 